\title{
A Tapuya "Equestrian Nation"? Horses and Native Peoples in the Backlands of Colonial Brazil
}

\author{
Felipe Vander Velden
}

\author{
This chapter is dedicated to \\ Roberto, vaqueiro (cowboy), \\ Xukuru do Ororubá, \\ Pernambuco, Brazil
}

\section{Introduction}

The horse (Equus caballus Linnaeus 1758) was introduced to the Americas at the end of the fifteenth century: on his second transatlantic journey to the Caribbean, Christopher Columbus brought horses that landed on the island of Hispaniola in November 1493. ${ }^{1}$ Several narratives of the conquest insist that these animals were fundamental to the advance of Iberian colonization in America, not only because they allowed men and cargo to be transported over often difficult terrain, but also because of the terror they inflicted on native peoples who could not understand the strength and impetuosity of this previously unknown animal, nor its strange amalgamation with a (seemingly) human rider. ${ }^{2}$ But Matthew Restall, in his fundamental analysis of the myths of the Spanish conquest of the New World, argues that the spectacular role assigned to the action of horses was above all wishful

1 John Johnson, "The introduction of the horse into the Western Hemisphere," The Hispanic American Historical Review 23:4 (1943): 587-610.

2 Johnson, "The introduction"; Robert Cunninghame Graham, The horses of the conquest: a study of the steeds of the Spanish Conquistadors (Norman: University of Oklahoma Press, 1949). 
thinking, and that horses were not as decisive as depicted by the heroic historiography of conquest. ${ }^{3}$

From very early in the history of American colonization, these formidable animals were adopted by indigenous peoples across the continent in processes that have been (critically) called "equestrian complexes" (complejos ecuestres), "horse cultures,"4 or more recently, "horse nations." 5 The historiography has focused on these relationships between Amerindian groups and horses in various parts of the New World, with special attention to the Great Plains, but South America was also the scene of multiple processes involving the adaptation of Indian life to the use of horses; in certain cases this implied radical changes in means of subsistence, regional exchange networks, and the cosmologies and social practices of these peoples. Classic cases of these "horse nations" in lowland South America include the native groups of the Pampas, Patagonia, and Araucania, ${ }^{6}$ as well as the Gran Chaco, particularly the Guaykuru-speaking peoples, certain groups in central Argentina, ${ }^{8}$ and others in the La Guajira

\footnotetext{
${ }^{3}$ Matthew Restall, Sete mitos da colonização espanhola (Rio de Janeiro: Civilização Brasileira, 2006), 238-239. Gregson suggests that it was ironic that the supposed military advantage of the mounted Spaniards was demolished a few decades after their arrival with the adoption of the horse by many Amerindian peoples (Ronald Gregson. 1969. "The influence of horse on Indian cultures of Lowland South America," Ethnohistory 16:1 (1969), 33.

4 Eduardo Galvão, "O cavalo na América indígena: nota prévia a um estudo de mudança cultural," Revista do Museu Paulista (nova Série) 14 (1963): 221-232; Miguel A. Palermo, "Reflexiones sobre el llamado 'complejo ecuestre' en la Argentina," Runa 16 (1986): 157-178; François-René Picon, "Le cheval dans le Noveau Monde: histoires culturelles," Études Rurales 151-152 (1999): 51-75.

5 Peter Mitchell, Horse nations: the worldwide impact of the horse on Indigenous societies post-1492 (Oxford: Oxford University Press, 2015).

6 Palermo, "Reflexiones"; Mitchell, Horse nations, 253-301; Miguel A. Palermo, 1988. "La innovación agropecuaria entre los indígenas Pampeano-Patagonicos: genesis y procesos," Anuario del IEHS 3 (1988): 43-90; Lidia Nacuzzi, Identidades impuestas: Tehuelches, Aucas y Pampas en el Norte de la Patagonia (Buenos Aires: Sociedad Argentina de Antropología, 1998); Lidia Nacuzzi, "Los grupos nómades de la Patagonia y el Chaco en el siglo XVIII: identidades, espacios, movimientos y recursos económicos ante la situación de contacto. Una reflexión comparativa," Chungara: Revista de Antropología Chilena 30:2 (2007): 221-234.

${ }^{7}$ Mitchell, Horse nations, 231-251; James Saeger, The Chaco mission frontier: the Guaycuruan experience (Tucson: The University of Arizona Press, 2000).

8 Nacuzzi, "Los grupos nómades"; Helmut Schindler, "Equestrian and Non-Equestrian Indians of the Gran Chaco during the Colonial Period," Indiana 10 (1985): 452.
} 
peninsula on the borderlands between Colombia and Venezuela, where the Wayuu or Guajiro still live today. ${ }^{?}$

In Brazil, the best known are the Kadiwéu or Mbayá-Guaikuru (in the state of Mato Grosso do Sul), who were even called "horse-riding Indians" (Índios Cavaleiros) in reference to their ability to ride and use horses, which helped them resist conquest by the Iberian colonial powers for nearly two hundred years. ${ }^{10}$ Examples of the adoption of horses with more circumscribed sociocultural impacts are found in the Venezuelan Ilanos, ${ }^{11}$ in the savannas of northern Brazil and southern Guyana, ${ }^{12}$ and among the Chiriguano, who rode captured horses as war booty in the Andes de Charcas in the seventeenth century. ${ }^{13}$

Colonial documentation (which is certainly sparse and scattered, but perhaps still not fully explored) depicts the emergence, in the sixteenth and seventeenth centuries, of other horse nations among indigenous societies in a region with poorly explored ethnohistory and ethnology. This region is the semiarid backlands of north-eastern Brazil (the sertão), ${ }^{14}$ where since the earliest days of colonization, horses seem to have been received and adopted to great advantage by the native peoples collectively known as Tapuya - a generic term referring to

${ }_{9}^{9}$ Mitchell, Horse nations, 220-231; Gustav Bolinder, Indians on horseback (London: Dennis Dobson, 1957).

10 Mitchell, Horse nations, 244-247; Ricardo Franco de Almeida Serra, "Parecer sobre o aldeamento dos índios Uaicurus e Guanás com a descripção dos seus usos, religião, estabilidade e costumes (1803)," Revista do Instituto Histórico e Geográfico Brasileiro 7 (1845): 204-218; Antonio de Pádua Bertelli, Os fatos e os acontecidos com a poderosa e soberana Nação dos Índios Cavaleiros Guaycurús no Pantanal do Mato Grosso, entre os anos de 1526 até o ano de 1986 (São Paulo: Uyara, 1987); Chiara Vangelista, Confini e frontiere: alleanze e conflitti interetnici in America Meridionale, sec. XVIII (Torino: Il Segnalibro, 2001); Heather Roller, "On the verge of total extinction? From Guaykurú to Kadiwéu in nineteenth-century Brazil," Ethnobistory 65:4 (2018): 647-670.

11 Mitchell, Horse nations, 227-231.

12 Thomas Henfrey, 2017. Wapishana ethnoecology: a case study from the South Rupununi, Guyana (Lethem: The Wapishana Wadauniinao Ati'o, 2017): 127-129.

13 Thierry Saignes, "La guerra 'salvaje' en los confines de los Andes y del Chaco: la resistencia chiriguana a la colonización europea," Quinto Centenario 8 (1985): 114-115.

${ }^{14}$ In Portuguese, sertão has multiple meanings and an unclear origin. Here, it refers to a region (inland northeastern Brazil) known for its semiarid climate and xerophyte vegetation. During the colonial period, this region was also defined in contrast with the coastal area by the indigenous groups generally known as the Tapuya; the Europeans considered it a hostile environment, inhabited by a sparse population of wild and barbaric people. 
groups generally hostile to the Europeans (but with whom they sometimes forged ephemeral alliances) who lived inland and spoke various languages, ${ }^{15}$ as opposed to the Tupi-speaking peoples living on the coast which was quickly occupied by the Europeans after $1500 .{ }^{16}$ The brutal occupation of this region by cattle ranching between the sixteenth and the eighteenth centuries eventually interrupted this experience of transforming lives and cultures among the Tapuya groups before they could be properly documented. In fact, it is interesting to note that the same "pastoral expansion front" 17 that brought them the horse also ended up destroying most of them. However, this Tapuya "equestrian culture" may still be glimpsed within the intense material and symbolic relationships that the present inhabitants of the region, called sertanejos, have with their horses and the great esteem and value accorded to the cowboy as a professional, including by the indigenous peoples who inhabit this part of Brazil.

This chapter brings together sparse references which have not been addressed by those authors who have previously discussed the trajectory of equines in the New World ${ }^{18}$ suggesting the adoption and

15 Although the languages spoken by most of these peoples are virtually unknown, several elements suggest that they may have belonged to the Macro-Jê linguistic family, largely because of the fact that the four languages of the Kariri family and Yaathê (spoken by the Fulni-ô in Pernambuco) are grouped within Macro-Jê, which includes many other indigenous languages of central Brazil (see Eduardo Rivail Ribeiro, "Macro-Jê," in Encyclopedia of Language and Linguistics, volume 7, ed. Keith Brown (Oxford: Elsevier, 2006), 422-426.

${ }^{16}$ As has been known since at least Robert Lowie, "Tapuya" does not designate a specific ethnolinguistic or cultural ensemble, but rather a location: those groups that lived in the interior of northeast Brazil during the colonial period and spoke languages other than the Tupi in the coastal areas. In this article I use this term mainly because I am discussing sources of this period which refer to these peoples as Tapuya, sometimes referring to some groups in particular - with great emphasis on the Tarairiú, the main Tapuya actors in the history of clashes between the Dutch and the Portuguese (Robert Lowie, "The 'Tapuya'," in Handbook of South American Indians, vol. 1: The Marginal Tribes, ed. Julian H. Steward (Washington: Government Printing Office, 1946), 556); see also John Manuel Monteiro, "The crises and transformations of invaded societies: coastal Brazil in the sixteenth century," in The Cambridge History of the Native Peoples of the Americas, ed. Frank Salomon and Stuart B. Schwartz (Cambridge: Cambridge University Press, 1999), 973-1023; Cristina Pompa, "Religião como tradução: missionários, Tupi e "Tapuia” no Brasil colonial" (PhD diss., Universidade Estadual de Campinas, 2001).

${ }^{17}$ Darcy Ribeiro, Os índios e a civilização (São Paulo: Companhia das Letras, 1996).

18 Galvão, "O cavalo na América do Sul"; Palermo, "Reflexiones"; Palermo, "La innovación agropecuaria"; Picon, "Le cheval das le Noveau Monde"; Mitchell, Horse nations. 
use of horses by some Tapuya groups (especially those in the north known as Tarairiu or Janduí), as well as minimal documentary indications pinpointing the transformations brought about by the introduction of this animal into the daily life and social practices of these peoples. Moreover, it suggests (without any pretensions of defending ethnohistorical continuities), that this Tapuya equestrian culture may still be alive in the relations that the indigenous peoples in the Brazilian Northeast have with their horses and cattle, arguing that they also were and are part of the culture of the sertanejo cowboy. ${ }^{19}$ In this way, we begin the task of provincializing (or particularizing) the formation of the "civilization of cattle and leather," as defined by Capistrano de Abreu in the north-eastern backlands of Brazil, ${ }^{20}$ which was shaped by a myriad of distinct social and historical processes and not, as the great narrative of the "pastoral expansion front" would hold, by an unavoidable expansion of the European model of cattle raising in an area inhabited by societies that (when they were not previously erased by the image of a "demographic void" or "desert") quickly gave way to animals and their accompanying human beings the so-called "extinction chronicle" of the Tapuya groups. ${ }^{21}$ We know from the pioneering works of Luís Mott, ${ }^{22}$ which showed how the establishment and consolidation of farms in the region depended heavily on the work of indigenous cowboys, that cattle ranching in the Brazilian semiarid region did not simply extinguish or expel the indigenous peoples.

\section{The first Brazilian horses}

The horse arrived in north-eastern Brazil through the efforts of Governor-General Tomé de Souza in 1549, who also brought oxen, sheep, and goats from the Cape Verde Islands and the Azores to the

19 Euclides da Cunha, Os sertões (Rio de Janeiro: Ediouro, 1967); Luís da Câmara Cascudo, Vaqueiros e cantadores (São Paulo: Global, 2004); Gustavo Barroso, Terra de sol (Fortaleza: Editora ABC, 2006).

20 João Capistrano de Abreu, Capitulos de história colonial: 1500-1800 (Brasília: Conselho Editorial do Senado Federal, 1998).

21 John Hemming, Red gold: The conquest of the Braqilian Indians (Cambridge: Harvard University Press, 1978), 345-376.

22 Luiz Mott, "Os índios e a pecuária nas fazendas de gado do Piauí colonial," Revista de Antropologia 22 (1979): 61-78. 
headquarters of the General Government in Salvador. ${ }^{23}$ Records show that shortly thereafter, in 1578, many horses were brought to the Northeast by the Dutch. ${ }^{24}$ These animals were initially confined to the coastal region, where they seem to have adapted very well, as Gabriel Soares de Souza attests in an excerpt written in Bahia in 1587 that illustrates not only their arrival in Pernambuco but also their adaptation to the conditions they were likely to encounter among the Tapuya living in the backlands:

The mares went to Bahia from Cape Verde, from which the land was populated, so that, in principle, costing 60,000 reis and more, for which they carried there many mares and horses every year, they multiplied in such a way that they were worth now ten and twelve thousand reis; and there are men who have on their farms 40 and 50, which breed every year [...]. The mares of Bahia are as beautiful as the best of Spain, from which are born beautiful horses, and great runners, which until the age of five years are well conditioned, and for the most part as they pass from here, they experience cruelty and they become very restless, but delicate and jealous; so, they, like the mares go unshod, but since their hooves are very hard this causes no problems. From Bahia they take the horses to Pernambuco for merchandise [...]. ${ }^{25}$

It is very probable that these hard-hoofed animals, in the company of cattle and other animals, soon began to penetrate the interior of the region, spreading throughout the Brazilian biome known as caatinga. This biome, which comprises the landscapes of the sertão, is found on an expansive plateau and features a tropical, semiarid climate (hot and dry), rocky soils, xerophyte vegetation naturally adapted to dry conditions, with high temperatures and an average annual rainfall of

23 Arthur Mariante and Neusa Cavalcante, Animais do descobrimento: raças domésticas da história do Brasil (Brasília: Embrapa, 2006), 82; Ana Lúcia Camphora, Animais e sociedade no Brasil dos séculos XV T a XIX (Rio de Janeiro: ABRAMVET, 2017), 105.

${ }^{24}$ Camphora, Animais e sociedade, 105.

25 Gabriel Soares de Souza, Tratado descritivo do Brasil em 1587 (São Paulo: Companhia Editora Nacional, 1938 [1587]), 175-176 (my translation, emphasis added). The remarkable multiplication of those animals (namely, their availability) provides one of the main conditions for the adoption of the horse by Native peoples, according to Helmut Schindler, "Equestrian and Non-Equestrian," 452. 
700-800 millimeters concentrated in three or four months of the year and periodic droughts of varying severity. The São Francisco River is the only truly permanent watercourse; all the other rivers and streams in the region dry up partly or entirely during dry periods. ${ }^{26}$ Because of these climatic adversities, the ranching settle0ments mainly followed the rivers and other reliable water sources, such as those located in the mountains (serras) and swamps which enjoy higher humidity and a milder climate where the ecological conditions were better adapted for raising animals. Peter Mitchell ${ }^{27}$ has shown that horses need less water and food than cattle, and can survive longer droughts and live on poorer-quality forage; furthermore, raising cattle requires more human intervention, more complex structures, and greater investments in terms of work than raising horses. ${ }^{28}$ Additionally, horse meat is nourishing and a plethora of useful artifacts can be derived and fabricated from their bodies. Using these animals for transportation or hauling cargo also requires various articles, as can be seen in the sophisticated riding articles of the Tehuelche of Patagonia ${ }^{29}$ and in the leatherwork of the Kadiwéu. ${ }^{30}$ This may explain why the horse was domesticated, and why this probably took place on the western steppes of Eurasia, where the climate is extreme ${ }^{31}$. This hardiness could have helped horses spread among the indigenous peoples of the semiarid sertão of the Brazilian Northeast, as in Argentinean Patagonia, for example, ${ }^{32}$ but this hypothesis still requires investigation.

${ }^{26}$ IBGE (Instituto Brasileiro de Geografia e Estatística), Geografia do Brasil: grandes regiões Meio-Norte e Nordeste (Rio de Janeiro: IBGE, 1962 - Biblioteca Geográfica Brasileira, série A, v. 3, n. 17); see also Manuel Correia de Andrade, A Terra e o Homem no Nordeste (São Paulo: Brasiliense, 1963).

27 Mitchell, Horse nations, 43-44.

28 Carole Ferret, Une civilisation du cheval: les usages de l'équide de la steppe à la tä̈ga (Paris: Éditions Belin/IFEAC, 2009), 40.

${ }^{29}$ John Cooper, "The Patagonian and Pampean hunters," in Handbook of South American Indians - volume 1: The marginal tribes, ed. Julian Steward (Washington: Government Printing Office, 1946), 145.

30 Ana Lucia Herberts, “Os Mbayá-Guaicurú: área, assentamento, subsistência e cultura material” (Master's thesis, Universidade do Vale do Rio dos Sinos, 1998).

31 See also Marsha Levine, "Domestication and early history of the horse," The domestic horse: the origins, development and management of its behavior, ed. D. S. Mills and S. M. McDonnell (Cambridge: Cambridge University Press, 2005): 5-22.

32 See Palermo, "Reflexiones"; and Palermo, "La innovación agropecuaria." 
The expansion of the availability of the horse throughout the northeastern semiarid sertão was linked to the spread of cattle ranching inland, the main driver of the region's conquest and colonization. According to Alípio Goulart, in a study of the horse in the formation of Brazil, these animals followed the territorial diffusion of cattle, since "there is no extensive breeding of cattle without cowboys, nor cowboys without horses." 33 Horses must thus have been adopted by the many Tapuya groups living in that landscape: exchanged with the Portuguese (and later, between 1630 and 1654, also with the Dutch), stolen from the herds that developed along the rivers, or even captured as they spread on their own through the backlands, although there are no records of feral horses in north-eastern Brazil as seen in other parts of the Americas and the rest of the world. ${ }^{34}$

Historical scholarship on the conquest of the sertão within the northern captaincies shows that farms began to rapidly expand inland, and also states that free-ranging cattle often spearheaded this process, gaining ground ahead of their human companions and frequently reaching indigenous villages even before European settlers appeared. ${ }^{35}$ In this trajectory, it is reasonable to suppose that horses may have accompanied cattle in their autonomous penetration throughout the interior, and that herds of equines may also have spread to parts of the colonial Northeast. A Dutch map of the region, published by Joan Blaeu in 1647 from the original by George Markgraf of 1643 and illustrated with images by Frans Post, ${ }^{36}$ includes in its upper-right corner some examples of the fauna of this part of Brazil: to the right two rheas, to the left what seem to be peccaries. But in the center are

33 José Alípio Goulart, O cavalo na formação do Brasil (Rio de Janeiro: Editora Letras e Artes, 1964), 2 (my translation).

34 Michelle Taylor, Feral and semi feral horses: a useful guide and overview (Scotts Valley: CreateSpace Independent Publishing Platform, 2016).

${ }^{35}$ Hemming, Red gold; Luís A. Moniz Bandeira, O feudo. A Casa da Torre de Garcia d'Ávila: da conquista dos sertões à independência do Brasil (Rio de Janeiro: Civilização Brasileira, 2000); Marcos Galindo, O governo das almas: a expansão colonial no país dos Tapuias (1651-1798) (São Paulo: Hucitec, 2017).

36 Peter James Whitehead and Marinus Boeseman, A portrait of Dutch 17th century Brazil: animals, plants and people by the artists of Johan Maurits of Nassau (Amsterdam: NorthHolland Publishing Company/ Koninklijke Nederlandse Akademie van Wetenschappen Verhandelingen Afd. Natuurkunde, Tweede Reeks, deel 87, 1989), 151-154. 
two animals: the one on the left very much resembles a horse (aside from its tail), while the one on the right looks like a deer (Fig. 1).

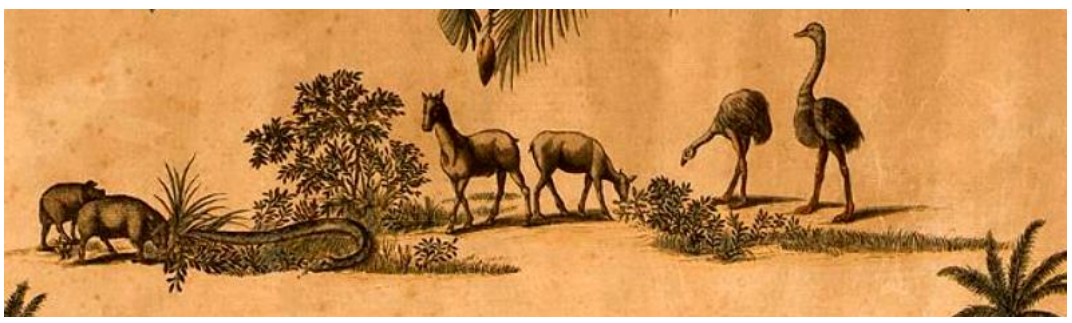

Fig. 1. Brasilia qua parte paret Belgis (detail), 1659 [1647]. (reproduced here with permission from Leiden University Libraries, COLLBN 004-08-025/032).

Is this a sign that feral horses existed in the Brazilian backlands, running wild with rheas and peccaries? We cannot be sure. ${ }^{37}$ But it is plausible to suggest that in addition to slaughtering the animals introduced by colonization (as the documentary evidence so abundantly shows), indigenous peoples in the sertão also adopted these

37 Describing this same pair of animals, Whitehead and Boeseman claim they are two deer "with rather heavy legs and long heads like horses, possibly intended to be pampas deer (Ozotoceros bezoarticus), described under caguacu-ete in the Historia [Naturalis Brasiliae, by Piso and Marcgraf]" (Whitehead and Boeseman, A portrait of Dutch 17th century, 157). But why does at least one of these presumptive deer look so much like a horse? De Bruin also mentions "two deer," suggesting that they may be red brocket deer (Mazama americana), "endemic to the whole of Brazil" (Alexander De Bruin, 2016. Frans Post: Animals in Brazil (Amsterdam: Rjksmuseum, 2016), 31, 73). In fact, the map from the University of Leiden Library contains a legend: Harten, "deer [plural]" in Dutch. What appear to be two small horns can be seen on the head of the animal on the left side. Even so, the similarity to a horse's head still remains: can we suggest that wild horses, running free like the native ungulates, served as a model for the two "deer"? Note that not all copies of this map contain the legend: "[ $\mathrm{t}]$ he various editions [of the map] exhibit small differences" (Bartira Barbosa, José Ruiz-Peinado, Ricardo Piqueras and Scott Allen, Afroindigenous spaces on the map Brasilia qua parte paret Belgis (Barcelona: Editora Universitária UFPE/Universitat de Barcelona, 2013), 13. Note that Wilma George has highlighted the relative accuracy of animal representations on ancient maps: Wilma George, Animals and maps (London: Secker and Warburg, 1969); see also Margriet Hoogvliet, "De ignotis quarumdam bestiarum naturis: texts and images from the bestiary on Mediaeval maps of the world," in Animals and the symbolic in Mediaeval art and literature, edited by L. R. Houwen (Groningen: Egbert Forsten, 1997), 189-208. 
animals stolen from farms or and captured the cattle and horses that wandered throughout the region on their own. This is described by Ernst van den Boogaart in his description of Dutch relations with the Tarairiu after 1648: "In later years, the Tarairiu captured stray horses and sold them to Company officials, such as Persijn and Samuel Engelaer," receiving in return axes, mirrors, knives, scissors, and other metal implements. ${ }^{38}$ Similarly, a letter from van Stetten, sent from Natal to the High Councilors in Recife in April 1645 and mentioning unrest among settlers during the revolt in Brazil, states that "thousands of animals and wild horses..." could be seen throughout the interior of Rio Grande, ${ }^{39}$ perhaps referring to animals that had become feral. The Danish soldier Peter Hajstrup, who served the Dutch West India Company in Brazil, recorded men "charged with rounding up wild horses in the Sertão" in 1652.40

We should bear in mind that the region occupied by the peoples known as Tapuya, if not exactly on the margins of Portuguese colonization (due to the importance of cattle and ranching in the colony), was in fact "ecologically and climatically poorly suited to intensive agriculture," which according to Mitchell ${ }^{41}$ turned it into the perfect setting to develop an equestrian culture among the native peoples. Furthermore, according to the same author, the horse found human populations with technological assemblages and livelihoods similar to those of other Amerindian horse nations. The Tapuya were hunter-gatherers or mixed hunting and fishing with small-scale horticulture; their constant mobility may be the most frequently mentioned characteristic of these societies in the historical sources,

\footnotetext{
38 Ernst van den Boogaart, "Infernal allies: The Dutch West India Company and the Tarairiu, 1631-1654," in Johan Maurits van Nassau-Siegen: a bumanist prince in Europe and Brazil. Essays on the occasion of the tercentenary of his death, ed. Ernst van den Boogaart, H. R. Hoetnik and J.P.J. Whitehead (The Hague: The Johan Maurits van Nassau Stichting, 1979), 531, emphasis added.

${ }^{39}$ Quoted in Benjamin Teensma, "O diretorado do Predicante Jodocus van Stetten no ano 1645, sobre uma suposta mina de prata nas margens do Rio Sucuru na Paraíba," in Brazilie in de Nederlandse archieven (1624-1654): Oude West Indische Compagnie: correspondentie van de Heren XIX en Notulen van de Hoge en Secrete Raad van Brazilië / O Brasil em arquivos neerlandeses (1624-1654): Companhia das Índias Ocidentais velha: Cartas enviadas pelos Diretores XIX Atas diárias do Alto e Secreto Conselho do Brasil, ed. Marianne Wiesebron (Leiden: Leiden University Press, 2011), 39.

40 Peter Hansen Hajstrup, Viagem ao Brasil (1644-1654) (Recife: Cepe Editora, 2016), 93.

${ }^{41}$ Mitchell, Horse nations, 4.
} 
which may have also favored adoption of this animal by these groups ${ }^{42}$ and their subsequent conversion into something like "equestrian nomads." 43

\section{Janduí's horses}

The Dutch occupation of Pernambuco and surrounding captaincies in Northeastern Brazil (1630-1654) produced some of the main accounts of both the animals they encountered there and the Tapuya groups they met in the vast hinterland of the sertão. On this first point, it is well known that the Dutch seem to have marveled not only at the neotropical species they encountered, but also at the domesticated animals from Europe or Africa which were already present in Brazil thanks to earlier Portuguese settlers.

However, Peter James Whitehead ${ }^{44}$ notes that domestic animals (especially those from the Old World) aroused little interest among observers in the lands discovered after the fifteenth century, with the important exception of Dutch artists and naturalists in occupied Brazil:

Of great importance are the paintings of domestic animals, so frequently forgotten by artists recording an exotic fauna [...]. In volume 3 of the Theatri are seven very fine paintings of breeds of sheep, a dog and a splendid white cat called Jochim. ${ }^{45}$

Nevertheless, so far there has been almost no analytical attention to these texts and engravings which depict beings already familiar to Europeans, almost as if this domestic fauna were of less interest to contemporary scholars than to their counterparts in the early modern period. Dutch artists in Brazil painted and drew many animals that were not among tropical South America's native wildlife, but rather were brought from the Old World and lived alongside indigenous and non-indigenous human groups. Yet while the wealth and strangeness of

\footnotetext{
42 Ibidem, 4.

43 Ibidem, 344-345.

44 Peter James Whitehead, "Georg Markgraf and Brazilian zoology," in Johan Maurits van Nassau-Siegen: a bumanist prince in Europe and Brazil. Essays on the occasion of the tercentenary of his death, ed. Ernst van den Boogaart, H. R. Hoetnik and J.P.J. Whitehead (The Hague: Johan Maurits van Nassau Stichting, 1979), 424-471.

45 Whitehead, "Georg Markgraf," 468.
} 
neotropical animals led these artists who recorded local species to often forget about the presence of domestic animals, this same fascination with the exotic seems to have contaminated the scholarship on the work of these artists with respect to its historical or scientific value: in fact, despite multiple investigations of zoological knowledge of Brazilian fauna associated with these texts and images from the sixteenth and seventeenth centuries, ${ }^{46}$ so far no research has questioned the presence, history, or condition of those taxa, which were just as foreign as the conquistadors that landed in the Americas from 1492 onward.

As a matter of fact, the Dutch were captivated by the qualities of the animals they found in Brazil, as were the Portuguese several decades earlier. In the words of Gaspar Barléu,

Not only these and other wild animals are found in Brazil, but also herds of small cattle and horses that were brought by the Portuguese and reproduce with notable fecundity. ${ }^{47}$

In the same spirit as the comments on the productivity and fertility of Brazilian lands which were common to many early observers, the Dutch praised the fertility, strength, and beauty of these animals, particularly horses. The Libri Principis, ${ }^{48}$ for example, contains a beautiful watercolor of a horse accompanied by a text praising the horses of Brazil, probably written by Johan Maurits of Nassau himself, according to Whitehead and Boeseman. ${ }^{49}$

Leaving the coastal zone in search of allies in the hinterland, the Dutch were surprised that certain Tapuya groups used horses, which

\footnotetext{
46 Whitehead, "Georg Markgraf'; Hendrik E. van Gelder, "Twee Braziliaanse schildpadden door Albert Eckhout," Oud Holland - Journal for Art of the Low Countries 75:1 (1960): 5-29; Dante M. Teixeira, "A imagem do paraíso: uma iconografia do Brasil Holandês (1624-1654) sobre a fauna e a flora do Novo Mundo," in Miscelânia Cleyeri (Rio de Janeiro: Index, 1995); Rebecca P. Brienen, "From Brazil to Europe: The zoological drawings of Albert Eckhout and George Marcgraf," in Early modern zoology. The construction of animals in science, literature and the visual arts, ed. Karl Enenkel and Paul Smith (Leiden: Brill, 2007): 273-314.

${ }^{47}$ Gaspar Barléu, História dos feitos recentemente praticados durante oito anos no Brasil e noutras partes sob o governodo ilustríssimo João Maurício, Conde de Nassan etc., ora governador de Wesel, Tenente-General da Cavalaria das Provincias-Unidas sob o Príncipe de Orange (Rio de Janeiro: Serviço Gráfico do Ministério da Educação, 1940), 139, my translation.

48 Libri Principis, volume I (Rio de Janeiro: Editora Index, 1993), 10.

49 Whitehead and Boeseman, A portrait of Dutch 1 $7^{\text {th }}$ century, 41.
} 
may have been acquired before they arrived or which they themselves may have introduced, as subsequent Portuguese documents would claim. Dutch sources mention the horses incorporated by the Tarairiu, with whom they forged alliances, especially the group known as Janduí (Nhanduí or Iandu1), which were named after their main leader who was a great ally of the Dutch. These alliances, however, were always very unstable and marked by intercultural disagreements. ${ }^{50}$ Horses appear to have been very useful in rustling and killing the European cattle that spread through the sertão, and of course, in war. Cristina Pompa states that the Tapuya (Janduí) groups of semiarid north-eastern Brazil "made use of the horse. This made their assaults more successful." 51

One of the best-known passages from the Dutch documentary evidence is the account by Roulox Baro, who when traveling in the "tapuya lands" (in the Rio Grande captaincy) in 1647 mentions the appearance of "four men on horseback, whom Jandui had dispatched to meet me":

Le vingt-deuxieme May arrivant nous marchames entre le Midy et le Couchat parmy des marets, bois, roches, et espines, sans trouver aucun sentier jusques à la riviere Itaquerra. Là je rencontray quatre hommes à cheval que Jandhuy envoyoit à ma rencontre, j'en renvoiay un aussitot, pour l'advertir de ma venuë. 52

\footnotetext{
50 See van den Boogaart, "Infernal allies"; Pedro Puntoni, A guerra dos bárbaros: povos indígenas e colonização do sertão Nordeste do Brasil, 1650-1720 (São Paulo: Hucitec/Edusp, 2002); Mark Meuwese, Brother in arms, partners in trade: Dutch-indigenous alliances in the Atlantic world, 1595-1674 (Leiden: Brill, 2012), 125-190; Carlos Henrique A. Cruz, "Tapuias e mestiços nas aldeias e sertões do Norte: conflitos, contatos e práticas 'religiosas' nas fronteiras coloniais" (PhD diss., Universidade Federal Fluminense, 2018).

51 Pompa, "Religião como tradução," 281, my translation.

52 "On May 22 we marched from noon to sundown among swamps, woods, stones, and thorns without finding any way to reach the Itaquerra River. There I found four men on horseback that Jandhuy had sent to meet me. I immediately sent one off to announce my arrival" (Roulox Baro, "Relation du voyage de Roulox Baro. Interprete et Ambassadeur ordinaire de la Compagnie des Indes d'Occident de la part des illustrissimes seigneurs des Provinces Unies au pays des Tapuies dans las terres fermes du Brasil. Commencé le troisiesme Avril 1647. Et fini le quatorsiesme Juillet de la mesme anné," in Relations veritables et curieuses de l'isle de Madagascar et du Bresil ave l'histoire de la derniere guerre faite an Bresil, entre les Portugais et les Hollandois, ed. Pierre Moreau (Paris: Chez Augustin Courbé, 1651), 215.
} 
When he returned to Recife, Roulox Baro borrowed a horse again from a Tapuya leader, Vavajapu, so that he could travel faster. ${ }^{53}$

The fact that the Tarairiu owned horses is interesting, because it contradicts Ernst van den Boogaart's claim that the Dutch stopped asking their Tapuya allies to work in the sugar industry, grow crops, or raise cattle after 1641 because they did not consider them "suitable for such tasks." ${ }^{4}$ We know nothing of the existence of herds of horses, other equines, or other animals in the indigenous villages in the backlands, but some of these animals were known to exist there, acquired through looting, exchanges with Europeans, or by capturing stray or even feral animals.

Two of the gouache or oil-on-paper engravings found in the Theatrum Rerum Naturalium Brasiliae ${ }^{55}$ attributed to Albert Eckhout, which depict "Tapuyas," are particularly striking. In Fig. 2, the individual depicted seems to wear boots or riding leggings and wears across his back what looks to be the hide of a large animal, perhaps a deer, although the fur seems slightly denser in the painting; it may be a cowhide or even horsehide, but it is hard to say. It is also difficult to identify the sketched objects below and behind the man in the foreground, but what appears to be a feathered hat in the lower-right corner may refer to one of the first gifts sent to Janduí by the Dutch commander Georg Gartsman. ${ }^{56}$ In this case, we would be looking at a portrait of the great Tarairiu leader from the period of Dutch occupation in Brazil.

Fig. 3 depicts a "Tapuya hunter or warrior" (Tapuyarum alius venatur aut miles). According to Ehrenreich, this Tapuya man also carries "a fur cloak that reaches to his calves and to which a handful of arrows is stuck." ${ }^{57}$ Ehrenreich is unable to determine whether it is a quiver or part of the cloak itself rolled to contain the arrows. ${ }^{58}$

\footnotetext{
53 Baro, "Relation du voyage de Roulox Baro," 245.

54 van den Boogaart, "Infernal allies," 528.

55 Theatrum Rerum Naturalium Brasiliae - Tomus III - Icones Animalium. BrasilHolandês/Dutch Brazil: Icones Animalium/Icones Vegetabilium (Rio de Janeiro: Index, 1993). ${ }^{56}$ van den Boogaart, "Infernal allies," 523.

57 Paul Ehrenreich, "Sobre alguns retratos de índios sul-americanos," Revista do Instituto Archeologico e Geographico Pernambucano 12:65 (1905): 29.

58 There is a third image that accompanies the two paintings analyzed here, which depicts a woman (Mulier brasiliensis) with a long cloak of skin or fur wrapped around the lower part of her body, below the waist.
} 


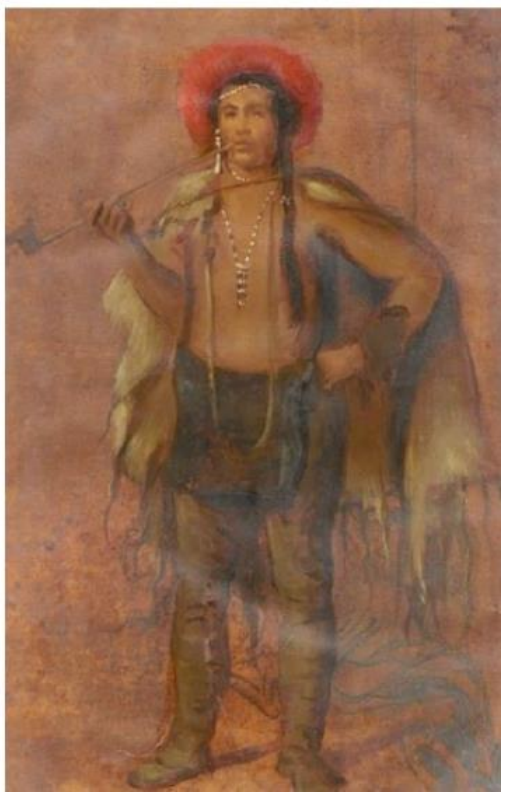

Fig. 2. Tapuyarum quidam. (Marg. in H. B., p. 270). Attributed to Albert Echkhout, c. 1640. Gouache and/or oil-onpaper. Liber picturatus A 34, The Jagiellonian Library Kraków, Special Collection Department, reproduced with permission.

Fig. 3. Tapuyarum alius venatur aut miles. Attributed to Albert Echkhout, c. 1640. Gouache and/or oil-on-paper. Liber picturatus A 34, The Jagiellonian Library Kraków, Special Collection Department, reproduced with permission.

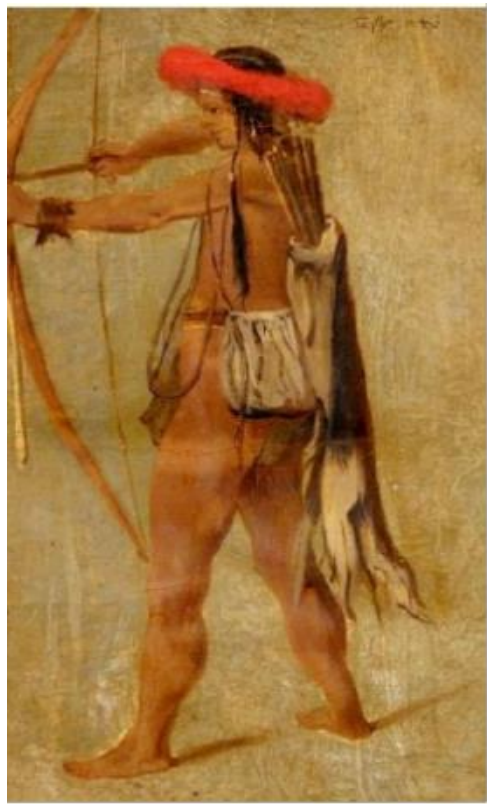


These paintings in the Theatrum are embroiled in a small controversy; Paul Ehrenreich ${ }^{59}$ has argued that the three drawings depict natives from the southern tip of South America (Araucanians or Puelches) who were met by the Dutch expedition to Chile in the midseventeenth century. He suggests that cloaks and leggings made of guanaco hides were commonly used among these peoples, and that even the other elements in the images (the short bow and arrows, the feather crowns, and the pipe) "agree perfectly with what we know of the original Chilean population." 60 Still, according to Ehrenreich, Christian Mentzel, the organizer of the Theatrum collection of images, confused these representations with that of the "Chilenses," mistakenly identifying these figures as "Tapuyas." Joppien shares the same opinion, arguing that the caption of the image Tapuyarum quidam (see Fig. 2) is incorrect, and rather a chief of "a Chilean people" (which he suggests to be the Chono) ${ }^{61}$ whom Eckhout (if this is indeed his work) met during the Dutch expedition to Chile led by Brouwer in 1643.62 The same author also notes the leggings and the cape of the character are made of guanaco skin, and that the drawings in the lower-right corner are "studies of the hat and the clothes" of the same personage. Whitehead and Boeseman also claim that the two engravings depict "Araucanian Indians." 63 It is interesting to combine these readings with later Portuguese sources presented by Fátima Lopes ${ }^{64}$ that support a comparison between the Tapuya and the Araucanians due to the military use of the horse. The mistake would thus be readily intelligible: Araucanians and Tapuya united in their bellicose nature, their resistance to the Iberian colonization, and their use of the horse in

59 Ehrenreich, "Sobre alguns retratos," 29-30; Paul Ehrenreich, "Über einige ältere Bildnisse südamerikanischer Indianer," Globus: Illustrierte Zeitschrift für Länder- und Völkerkunde 66:6 (1894): 29.

${ }^{60}$ Ehrenreich, "Sobre alguns retratos," 29-30.

61 On the Chono in Southern Chile, see John Cooper, "The Chono," in Handbook of South American Indians - volume 1: The marginal tribes, ed. Julian Steward (Washington: Government Printing Office, 1946), 47-54.

${ }^{62}$ Rüdiger Joppien, "The Dutch vision of Brazil: Johan Maurits and his artists," in Johan Maurits van Nassau-Siegen: a bumanist prince in Europe and Brazil. Essays on the occasion of the tercentenary of his death, ed. Ernst van den Boogaart, H. R. Hoetnik and J.P.J. Whitehead (The Hague: Johan Maurits van Nassau Stichting, 1979), 304-305.

${ }^{63}$ Whitehead and Boeseman, A portrait of Dutch $17^{\text {th }}$ century, 171.

${ }^{64}$ Fátima M. Lopes, Índios, colonos e missionários na colonização da capitania do Rio Grande do Norte (Natal: IHGRN, 1998). 
war. ${ }^{65}$ For this reason, we can suggest that these images do not represent "Chilenses" but instead Tapuya in north-eastern Brazil who were viewed and represented like the great adversaries of the Europeans in Chile who they resembled from the conquistadores' point of view. Egmond and Mason therefore disagree with the identification of these characters as Chileans: “(...) Ehrenreich's identification of these three persons as Chileans is questionable. The attributes of the men, who are labeled as 'Tapuyarum quidam' and 'Tapuyarum alius venator aut miles,' are not found among the residents of the regions visited by the expedition (...)." They argue that several of Eckhout's paintings are "montages" that blend physical attributes, body decorations, artifacts and natural species from different parts of the world. These combinations, moreover, "(..) do not mean that the figures depicted here are native Chileans." 66

The question is: why was bovine or equine leather (if that indeed is depicted in the figures above) the material chosen to equip and clothe these three Tapuya individuals? ${ }^{67}$ Was there any reason - prestige, distinction, power, magic — related to the use of leather, and especially leather made from animals brought by the Europeans into the backlands?

\section{Portuguese sources and the Jê-Tapuya controversy}

After the Dutch were driven out of north-eastern Brazil, references to the use of horses by the Tapuya groups (which the Portuguese apparently attributed to the Dutch invaders) continued through the seventeenth and eighteenth centuries, as the acts of these nomads (some now equestrian) continued to worry the colonial authorities. The Janduí were said to "retain the hatred of the Lusitanians" and also to

\footnotetext{
65 It is true that Natives in Chile (Araucanians or Chono) fighting on horseback and with large flocks and herds strongly impressed the Dutch who were in the region in 1642-1643 (see Henry Brouwer, "Relación del viaje de Hendrick Brouwer a Valdivia en 1643," in Opusculos varios de J.T. Medina, ed. Guillermo Felliú Cruz (Santiago: Imprenta Universitaria, 1928 [1646]), 81-127.

66 Florike Egmond and Peter Mason, "Albert E(e)ckhout, court painter," in Albert Eckhout: a Dutch artist in Brazil, ed. Quentin Buvelot (Den Haag: Royal Cabinet of Paintings Mauritshuis/Waanders Publishers, 2001), 120.

67 Susanna Harris and André Veldmeijer, eds., Why leather? The material and cultural dimensions of leather (Leiden: Sidestone Press, 2014).
} 
"herd horses and cattle."68 In the 1660s, Mathias Albuquerque Maranhão, capitão-mor of Paraíba, warned the Portuguese Crown about Tapuya attacks in the sertão which were largely "because they already have great numbers of horses, which they use according to ways they learned from the Dutch." 69 The documents repeatedly compare the Jandui with the Araucanians in the "Castilian Indies," who waged a relentless war against Spanish colonization in Chile, and were one of the most developed horse nations in South America. ${ }^{70}$ The documents also emphasized the prowess of the Tarairiu warriors who shot from horseback with great precision:

In addition to the weapons, the Tarairiú also adopted horses, which caused great terror and fear among the Portuguese (...) it was therefore expedient to make war against them '...because they have large herds of mares, and with discipline they can do us much harm...'. The fear was borne out, because the war of rapid assaults, with which the tapuyas were accustomed, became even more sudden and harmful, with the innovations brought by the Europeans, who made the tapuyas '...more empowered in the hinterland, where they have now become dominant, using saddled horses, with pistols and rifles fitted with silver and a lot of gunpowder and ammunition."71

Beyond these clashes, the sources suggest that Tapuya groups accumulated animals: in 1694, for example, João de Miranda and Teodósio de Oliveira Ledo set out to meet the "brave heathens who infested" the captaincies of northern Brazil, looting "all the cattle and horses with much damage to said heathens." 72 Some years earlier, in 1676-1677, the Capuchin friar Martin de Nantes, who traveled along with a war expedition to the "sertão Indians" of the São Francisco River, narrated how Tapuya "spies" encountered the horse. ${ }^{73}$ In these

\footnotetext{
${ }^{68}$ Cruz, "Tapuias e mestiços," 49.

${ }^{69}$ Letter to the Governor of Pernambuco, 01/09/1662, quoted in Lopes, Indios, colonos e missionários, 480, my translation.

70 Mitchell, Horse nations, 257-272.

${ }^{71}$ Lopes, Indios, colonos e missionários, 283-284, italics in the original, my translation.

72 Quoted in Cruz, "Tapuias e mestiços," 73. See also Lopes, Índios, colonos e missionários, 267.

73 Padre Martinho de Nantes, Relação de uma missão no rio São Francisco (São Paulo: Editora Nacional; Brasília: INL, 1979 [1706]).
} 
villages, a pastoral lifestyle was gradually taking shape: according to the eighteenth-century document quoted by Cruz ${ }^{74}$ the Pega Indians in Paraíba argued that "they lacked land for their crops and to raise their cattle," which probably also included horses. In 1665, it was noted that the Indians who settled in the Guairaru mountains (in Bahia) requested "some horses" as well as "cattle for corrals." 75 There are many records of Portuguese-Brazilian cowboys living among Tapuya groups in the northeast of the country; they certainly transferred their technical knowledge to the Indians and sometimes even provided animals, as in the case of the Janduís, who in the late seventeenth century lived off of "some cattle that the cowboys give them, and that they steal."

There is little doubt, therefore, that horses became part of the lives of various Tapuya peoples in the backlands of Brazil. It may consequently be necessary to nuance the assertion that "horses were little used" even "by the Portuguese military, because in the semiarid backlands where juremas [Mimosa hostilis] and other prickly shrubs" hindered the advance of animals, "the use of the horse was even more inconvenient and practically made it impossible to pursue the tapuyas, who were skillful at hiding in the caatinga." 77 The fact is that the sources mention the adaptation of the horse to the environment and to the practices of native peoples in this area. And, as is well known, the rustic vegetation of the caatinga did not prevent the formation of a civilization of cowboys (vaqueiros) who were and are skilled in the arts of riding and adept at dealing with cattle in the rugged landscapes in the northeastern sertão.

This reflection on the Tapuya equestrian culture also touches on another long-standing ethnohistorical issue, one that refers to the linguistic/ethnocultural identity of the indigenous groups known as

\footnotetext{
74 Cruz, "Tapuias e mestiços," 152.

75 Quoted in Solon A. Santos, Os Payayá no sertão das Jacobinas (1651-1706) (Curitiba: Editora Prismas, 2017), 239.

76 Helder M. de Macedo, "Relações entre índios e colonos nos sertões do Seridó, Capitania do Rio Grande, no século XVIII," Clio. Série Arqueológica 28 (2013): 1-17.

77 Valdeci dos Santos Junior, Os indios Tapuias do Rio Grande do Norte - Antepassados esquecidos (Mossoró: Universidade do Estado do Rio Grande do Norte/Grupo de Pesquisa História da Região Oeste do Rio Grande do Norte - Coleção Mossoroense, volume 1532as, 2008). See also Puntoni, A guerra dos bárbaros.
} 
Tapuya. ${ }^{78}$ Indeed, the adoption of horses by the Tarairiu (and other groups) has been identified as a criterion for denying that these groups were speakers of Jê languages, widely distributed across central-eastern Brazil. For example, Cristina Pompa points out that "the use of the horse has been one of the elements used in ethnology to support the theory that the Tapuya Tarairiú were not Jê."79 Apparently, this hypothesis was first raised by Schuller, ${ }^{80}$ who suggested that the difference between the Tapuya and the Jê was determined by the use of horses: the Tapuya adopted them while the Jê did not, even though they had secular contact with whites. Maybury-Lewis, while arguing for other reasons that the Tapuya were not Jê-speaking, did not agree with the use of the horse as a criterion for this conclusion: in his opinion, even if the Jê peoples ignored horses and in certain cases were very frightened of these animals, "such ignorance or fear can be overcome in a very short space of time by a group to whom horses become available." 81

In fact, according to Curt Nimuendajú, this seems to have been the case with the Eastern Timbira peoples in Maranhão:

At present all steppe Timbira breed pigs and fowls, even though only in small numbers - especially our Canella, whose village harbored some forty pigs (1933) and twelve horses, to boot. They like very much to handle horses and rapidly learn to become good riders. ${ }^{82}$

Other Jê-speaking peoples also adapted to an equestrian life and became herders, as seems to have occurred with the Akroá in northern Goiás and western Piauí around the 1740s. ${ }^{83}$

78 David Mead, "Caiapó do Sul, an ethnohistory (1610-1920)" (PhD diss., University of Florida, 2010), 87, note 1.

79 Pompa, "Religião como tradução,", 281, note 66, my translation.

80 Rudolf Schuller, "Zur Affinität der Tapúya-Indianer des 'Theatrum Rerum Naturalium Brasiliae'," Internationales Archiv für Ethnographie 21 (1912): 84.

81 David Maybury-Lewis, "Some crucial distinctions in Central Brazilian ethnology," Anthropos, bd. 60, h. 1/6 (1965): 341-342.

82 Curt Nimuendajú, The eastern Timbira (Berkeley: University of California Press/University of California Publications in American Archaeology and Ethnology no. 41, 1946), 75, emphasis added.

83 Juciene R. Apolinário, Os Akroá e outros povos indígenas nas fronteiras do sertão (Goiânia: Editora Kelps, 2006). 
In this way, certain Jê groups adopted the horse at some point, which does not allow us to definitively determine whether the Tapuya did or did not speak Jê languages because they used horses. The conditions needed for this (for Jê speakers to incorporate horses) appear to have been present: while Peter Mitchell is correct in pointing out that "[f]ree-ranging cattle may have been the prerequisite for Guaykurú to become equestrian nomads," 84 these were certainly present in the savannas of central and eastern Brazil, with cattle slowly colonizing territories before their human owners arrived. One example was the Krahó people, as noted by Melatti. ${ }^{85}$ This debate certainly invites us to further investigate the history and ethnography of the Jêspeaking peoples in central Brazil, especially in those areas where they were directly affected by "pastoral expansion." 86

\section{Concluding remarks: cowboy Indians today}

This chapter is designed to combine and confirm some information related to the adoption of the horse and the formation of an indigenous equestrian culture in the sertão regions of colonial northeastern Brazil, offering some insights that I hope will encourage new research on this topic, particularly in the documentary sources. It thus seems correct to state (as mentioned earlier) that horses became part of the life of several Tapuya peoples in the backlands of Brazil. But various questions still remain: to what extent did the Tapuya encounter and learn about horses and equestrian culture from Europeans? What kind of experiences did they have as workers or slaves on ranches? Did some Tapuya who were exposed to horses and ranching run away? Did they acquire horses at ranches, missions, or other European settlements and then run off with them? Or did they catch and tame wild horses? How did the relationships, connections, or interpenetrations between independent Tapuya and settlers or missionaries take place? Given the broad region covered here and the diversity of the indigenous peoples who are generically classified as Tapuya, one could imagine that the various Tapuya groups had different experiences, and that the answers

\footnotetext{
84 Mitchell, Horse nations, 238.

85 Júlio César Melatti, Índios e criadores: a situação dos Krabó na área pastoral do Tocantins (Rio de Janeiro: I.C.S/UFRJ, 1967), 122-137.

86 Ribeiro, Os indios e a civilização.
} 
to these questions might vary; some groups seem to have raised horses in significant quantities in their villages, while others may have simply stolen animals sporadically or even only attacked or killed these animals. But there is additional evidence that horses (and exotic domesticated animals in general) were incorporated into the indigenous socio-cosmologies of the Brazilian Northeast, which is revealed in the long term through contemporary practices.

There are a few records of the words for horses in the native languages once spoken in the sertão. The novelty and strangeness of these great herbivores can be seen in these names: the Kariri along the banks of the São Francisco River called them cabarú in the Kipeá language, as registered by the Jesuit Luiz Mamiani in the seventeenth century, borrowed from the Portuguese and possibly through the Tupinambá cavarú. ${ }^{87}$ Von Martius, traveling through the region in the nineteenth century, recorded caborro in the Massacará language (Bahia) and cöböning in Pimenteira (Piau1), in addition to two terms in Cariri, cavarru and cabarrí. ${ }^{8}$ Note that all these languages incorporated the Portuguese word for this new creature (cavalo). These terms show a process that is common to many Amerindian languages when faced with a strange, foreign creature, which is then named from the original European lexicon. According to Brown, ${ }^{89}$ this took place (in the case of horses) in $52 \%$ of the terms he researched: "it was usual for the Indians to use Spanish or Portuguese words for both horses and cattle," wrote Nordenskiöld. ${ }^{90}$ But $59 \%$ of the lexical items for "horse" discussed by Brown originated in native vocabularies. The term for the same animal in the Fulni-ô language, for example, attests to the value of the mobility achieved by these equestrian societies: thayô or thaithô, "the one who carries us." 91 And recalling the previous discussion about deer/horses in Blaeu's 1647 map (see above), we note that some Amerindian

87 Eduardo Rivail Ribeiro, "Tapuya connections: language contact in Eastern Brazil," Liames 9 (2009): 67-68.

88 Erland Nordenskiöld, Deductions suggested by the geographical distribution of some postcolumbian words used by the Indians of South America (Göteborg: Elanders Boktryckeri Aktiebolag, 1922), 58-62.

89 Cecil Brown, Lexical acculturation in Native American languages (Oxford: Oxford University Press, 1999), 76.

${ }^{90}$ Nordenskiöld, Deductions, 52.

91 Estevão Pinto, Etnologia Brasileira (Fulniô - Os últimos Tapuias) (São Paulo: Companhia Editora Nacional, 1956), 267. 
languages name the exotic horse after native deer, which seems to be the case for the Wayuu, who denoted the horse (ama) after the deer (irama), and even have a myth explaining how the latter transformed into the former. ${ }^{92}$

The fact is that horses, cattle, and all the material and symbolic paraphernalia associated with raising and coexisting with these beings became part of the identity of the inhabitants of north-eastern Brazil, including several of the indigenous populations that currently inhabit the region. Some time ago, I had the opportunity to spend time among the Xukuru do Ororubá Indians in Pernambuco. ${ }^{93}$ Although they have few farm animals today, many Xukuru men grew up on horseback, working with livestock on the surrounding farms. There is great respect for vaqueiros - men on horseback who work with cattle - which is reflected in the extreme care given to horses and in the widespread success of various mounted sports involving herding, such as pegas de boi and vaquejadas, and horse racing. This appreciation for the horse and for the cowboy way of life is corroborated by Olivia Ellis, for example, who describes the Xukuru as "fascinated by the hierarchy of the horse and cow; they are more valuable than agriculture." 94 She continues:

many Xukuru are drawn to "the myth of the vaqueiro (cowboy)." Because their territory has been occupied by fazendeiros since the colonization of Brazil, the Xukuru "have been observing the vaqueiro profession, and they dream of their horses, cattle, their animals." 95

The formation of the sertanejo society (or societies) thus also involved indigenous peoples in the region and their historical experiences with horses, oxen, and other domesticated animals. Many of the sociocultural practices and techniques related to animal husbandry in the Americas are known to have originated in the ways native people received the adventitious horse and the techniques used

92 François-René Picon, Pasteurs du Nouveau Monde. Adoption de l'élevage chez les indiens Guajiros (Paris: Éditions de la Maison des Sciences de l'Homme, 1983), 154.

${ }^{3}$ See Clarissa M. Lima, "Deus no céu e os índios na Terra: morte e vida numa aldeia Xukuru do Ororubá” (PhD diss., Universidade Federal de São Carlos, 2019).

94 Olivia Ellis, "Organizing indigeneity among the Xukuru do Ororubá of Brazil" (Master's thesis, University of Texas, 2010), 34.

95 Ellis, "Organizing indigeneity," 32. 
to capture, control, maintain, train, and use this animal. ${ }^{96}$ Ian Dyck suggests that the American ranching culture (especially rodeo) was shaped by large contributions from native Plains Indians cultures, perhaps because of the interactions between native and Anglo cowboys in the American West. ${ }^{97}$ It is therefore fair to suppose that the sertanejo cattle ranching culture that emerged in the north-eastern Brazilian backlands also owes many of its characteristics to the adoption of the horse (and other livestock) by the Tapuya who formerly occupied the region; this culture may also have been born from the colonial cattle ranches where many of these native people worked alongside cowboys of European origin. ${ }^{98}$ Another founding element may have been the north-eastern horse, called pé duro ("hard foot"), casco de burro ("donkey hoof") or cavalo crioulo nordestino ("north-eastern creole horse"), a small ecotype developed in the hinterland from animals introduced by the Portuguese in the sixteenth century. According to Goulart:

These animals helped in the process of inland settlement of the region, serving as mounts and the main means of transport (...). The Nordestino horse is suitable for work with cattle and flocks of goats and sheep that are raised in the caatinga, which consists of thorny vegetation and twisted branches. In this extremely rugged environment where little food or water is available, this breed became greatly adapted to semi-desert regions and the hard work of cowboys under these conditions. ${ }^{99}$

Perhaps the process in north-eastern Brazil resembled what took place in California, where adopting horses and riding equipment guaranteed the native peoples continuity because of the need for labor

96 Mitchell, Horse nations; Frédéric Saumade, "Ganadería, tauromaquia y subversión ritual: el retorno del mexicano y del indígena en el rodeo americano," in Comprender los rituales ganaderos en los Andes y más allá, ed. Juan Javier Rivera Andía, 365-400. (Bonn/Aachen: Shaker Verlag, 2014); Marília F. Kosby, Daniel Vaz Lima and Flávia Rieth, "Centauros de motocicleta: o cavalo como testemunha do "processo domesticatório’ do gaúcho,” Horizontes Antropológicos 23:48 (2017): 197-223.

97 Ian Dyck, "Does rodeo have roots in ancient Indian traditions?" Plains Anthropology 41: 157 (1996): 205-219. See also Peter Iverson, When Indians became cowboys: Native peoples and cattle ranching in the American West (Norman: University of Oklahoma Press, 1994).

98 Mott, "Os índios e a pecuária."

${ }_{99}$ Goulart, O cavalo na formação do Brasil, 3, my translation. 
on cattle ranches: throughout the nineteenth and twentieth centuries, this workforce was (and in many cases, still is) essentially indigenous. ${ }^{100}$ Returning to Pernambuco, many Xukuru men still long for the time when they could work as cowboys for the surrounding farmers: in a sense, it was their association with cattle ranches as employees, and their skills with cattle and horses, that guaranteed the survival of many families over generations in the Ororubá Range, a region traditionally occupied by the Xukuru.

This possible historical continuity, which extends from the adoption of the first horses (through theft, capture, donation, or trade) by the Tapuya in the sertão to the development of cowboy Indians in the Brazilian Northeast, suggests that ranching in the New World may not have been restricted to the Wayuu (Guajiro) on the ColombiaVenezuela border. ${ }^{101}$ It also indicates that if Philippe Descola ${ }^{102}$ is correct about the lack of animal domestication in the South American lowlands before the conquest, this did not stop animal raising and the accompanying technology introduced by the Europeans (or at least part of it, and certainly after various native adaptations) from being adopted. In this sense, horses may not have been considered to be in the same category as the native pets so common in South American indigenous villages (and widely recorded among many Amerindian peoples), ${ }^{103}$ which could eventually turn them into prey and food, something that almost never occurs with the familiarized native species living in close company with humans. But unfortunately, we know very little about how horses were adopted by the various Tapuya sociocosmological systems, although comparative investigations about the

100 Dyck, "Does rodeo have roots in ancient Indian traditions?"; Iverson, When Indians became cowboys; see also Lee Panich, "Indigenous vaqueros in colonial California: labor, identity, and autonomy," in Foreign objects: rethinking Indigenous consumption in American archaeology, ed. Craig Cipolla (Tucson: The University of Arizona Press, 2017), 187-203. 101 Picon, Pasteurs du Nouveau Monde.

102 Philippe Descola, "Pourquoi les indiens d'Amazonie n'ont-il pas domestiqué le pecari?” in De la prébistoire aux missiles balistiques. L'intelligence sociale des techniques, ed. Bruno Latour and Pierre Lemmonier (Paris: La Découverte, 1994), 329-344.

103 See, among many others, Philippe Erikso, "The social significance of pet keeping among Amazonian Indians," in Companion animals and us, ed. Anthony Podbersceck, Elizabeth S. Paul and James Serpell (Cambridge: Cambridge University Press, 2000): 726; Felipe Vander Velden, Inquietas companhias: sobre os animais de criação entre os Karitiana (São Paulo: Alameda, 2012); Luiz Costa, The owners of kinship: asymmetrical relations in Indigenous Amazonia (Chicago: HAU Books, 2017). 
presence of equines among Amerindian peoples can provide some clues from the meager documentary evidence which is available.

Further historical and ethnographic studies are needed to elucidate this multicultural formation of sertanejo society and the emergence of indigenous "equestrian cultures" in semiarid Brazil in order to provincialize, to a certain degree, the famous idea of the regional "cattle and leather civilization." It is a fact that the various indigenous peoples who occupy the same zone were active participants in this formation, and many proudly define themselves as vaqueiros: In fact, some colonial records of the region feature a certain lack of distinction between Indians and non-Indians with regard to outward identifiers, such as when Father Miguel de Carvalho described the cowboys in the Piauí sertão in 1697 as "these wretches wearing cowhides and looking like tapuias." 104 There is also one further question: if the native societies of the Brazilian sertão already used horses in the pursuit of their objectives in the seventeenth century, why are the adoption of horse riding and cattle ranching today still seen as signs of the loss of identity and acculturation of these peoples?

This group of equestrian technologies (including garments) which were probably developed or adapted by Tapuya groups, as suggested in the analysis of the two Dutch images above, and according to ample documentation for other horse nations in North America ${ }^{105}$ and South America ${ }^{106}$ as well as the occurrence of equine archaeological remains, indicate the material dimension of the phenomenon, which demands further archaeological research on the grounds that it might substantiate the emergence of these "Tapuya equestrian nations." In this way, zooarchaeological surveys concentrated in the former indigenous villages in the sertão should be attentive to remains of horses and other exotic animals in post-contact era sites. Another good place to look for evidence of the association between natives and horses would be the old Jesuit farms, identified by Santos in the north-eastern

104 Padre Miguel de Carvalho, 1938. "Descrição do sertão do Piauí remetida ao $\operatorname{Ilm}^{\circ}$. e $\mathrm{Rm}^{\circ}$. Sr. Frei Francisco de Lima, Bispo de Pernambuco," in As guerras dos Palmares: subsídios para sua história, ed. Ernesto Ennes (São Paulo: Companhia Editora Nacional), 373, emphasis added.

105 John Ewers, The borse in Blackfoot Indian culture (Washington: Smithsonian Institution Press, 1985).

106 Cooper, "The Patagonian and Pampean hunters"; Herberts, "Os Mbayá-Guaicurú." 
Brazilian state of Paraíba, ${ }^{107}$ several which occur in what is considered to have been the original territory of the Tarairiu. In this way, it is known that in "colonial sites domesticated animals predominate, especially those of economic importance such as cattle (Bos taurus), swine (Sus scrofa), sheep (Ovis aries), goats (Capra hircus), and equines," but that "there is still little information about the archaeofauna from archaeological sites during the four hundred years of the colonial period (the sixteenth century to the nineteenth century)."108

The references discussed here are fragmentary, but suggest that the relationship between certain Tapuya peoples and the horses introduced by the conquest extended beyond widespread myth in the interior of Brazil ${ }^{109}$ of the indigenous female ancestor - the cabocla brava, a savage and untamed Indian woman, since it is invariably a woman - living "in the wild" who is captured and tamed with the horse's lasso or by the hooves of a horse. This is one of the most common narratives that explains both the presence of indigenous blood in the formation of Brazilian society as well as the violent extinction of this same population through the masculine practices of war and sexual domination. ${ }^{110}$ This relationship also went beyond the mere use of indigenous workhands on the cattle farms of colonial Brazil. ${ }^{111}$ The horse did not appear in this region as only a tool for war and domination exclusively in the hands of the Europeans. It seems that the animal was also appropriated by native groups who utilized it in war and subsistence, and we can speculate that significant transformations also took place in their daily and ritual practices and in their technologies and cosmologies. Unfortunately, we have no

107 Juvandi de S. Santos, As fazendas de gado dos jesuitas na Paraíba colonial (João Pessoa: Eduepb/CNPq, 2015).

108 Albérico Nogueira de Queiroz, Olivia de Carvalho, Suely Martinelli, Márcia Guimarães and Cristiana Santana, "Distinctive archaeofauna occurrences recovered in Brazil: Iberian contribution in archaeological sites during the colonial period," in Book of Abstracts of the Encontro de Zooarqueologia Ibérica 2017 (EZI2017) and 5a Reunião Cientifica de Arqueomalacologia da Península Ibérica (5RCAPI). 26-29 April 2017, Faro - Portugal, eds. Maria João Valente, Cláudia Costa and Cleia Detry (Faro: Universidade do Algarve, 2017), 14.

109 John Manuel Monteiro, "Review of Oliveira, João Pacheco de. 1999. Ensaios de antropologia histórica. Rio de Janeiro: Editora UFRJ," Mana 8:1 (2002): 238.

110 Julie Cavignac, "A índia roubada: estudo comparativo da história e das representações das populações indígenas do Rio Grande do Norte," Caderno de História 2:2 (1995): 83-92.

111 Mott, "Os índios e a pecuária." 
information about this putative "indigenous leather civilization," and it is unlikely to ever be revealed. For this reason, perhaps the most that can be said of the "Tapuya equestrian culture" emerging in the sixteenth and seventeenth centuries is that "horses could find no more than a sporadic, tightly demarcated role."112

It is possible, as this same author maintains, that only time was lacking to develop a genuine native "horse nation" in north-eastern Brazil, since the other conditions (large spaces which were poorly suited to cash crops, sufficient pasture and water, lack of disease, and the presence of conflicting colonial powers, namely Portugal and Holland) seem to have been present. Nevertheless, if we consider that today's cowboy Indians express the continuity of this "Tapuya (or sertanejo) equestrian culture," then we must rectify Mitchell's claim that horse nations did not emerge in the "cerrado savannahs of Brazil," and that diseases and attacks directed at enslaving the natives "have inhibited the acquisition and consolidation of horse-keeping in the cerrado, notwithstanding the suitability of its grassland for horses." 113 If the question of the horse's adoption by the Jê-speaking peoples still remains open, depending on ethnographic information, the data collected here show that potentially related groups living in a similar biome seem to have adapted to equines with ease, at least during the seventeenth and eighteenth centuries.

\section{Acknowledgments}

This research is part of the ERC project BRASILLAE. Indigenous Knowledge in the Making of Science, directed by Dr. Mariana Françozo at Leiden University (The Netherlands) and funded by the European Research Council Horizon 2020 Research and Innovation Programme (Agreement No. 715423). I wish to thank Mariana Françozo, Carolina Monteiro, and Peter Mitchell for their critical appraisal of this article, Edwin Reesink and Albérico Nogueira de Queiroz for additional bibliographical suggestions, and Izabella Korczyńska (Biblioteka Jagiellońska, Poland) and Martij Storms (Leiden University Libraries, The Netherlands) for permission to use the images reproduced here. All translations are mine unless otherwise stated.

112 Mitchell, Horse nations, 230.

113 Ibidem, 355-356. 


\section{References}

Almeida Serra, Ricardo Franco de. "Parecer sobre o aldeamento dos índios Uaicurus e Guanás com a descripção dos seus usos, religião, estabilidade e costumes (1803)." Revista do Instituto Histórico e Geográfico Brasileiro 7 (1845): 204-218.

Andrade, Manuel Correia de. A Terra e o Homem no Nordeste. São Paulo: Brasiliense, 1963.

Apolinário, Juciene. Os Akroá e outros povos indigenas nas fronteiras do sertão. Goiânia: Editora Kelps, 2006.

Bandeira, Luís A. Moniz. O feudo. A Casa da Torre de Garcia d'Ávila: da conquista dos sertões à independência do Brasil. Rio de Janeiro: Civilização Brasileira, 2000.

Barbosa, Bartira, José Ruiz-Peinado, Ricardo Piqueras, and Scott Allen. Afroindigenous spaces on the map Brasilia qua parte paret Belgis. Barcelona: Editora Universitária UFPE/Universitat de Barcelona, 2013.

Barléu, Gaspar. História dos feitos recentemente praticados durante oito anos no Brasil e noutras partes sob o governodo ilustríssimo João Maurício, Conde de Nassau etc., ora governador de Wesel, Tenente-General da Cavalaria das Províncias-Unidas sob o Príncipe de Orange. Rio de Janeiro: Serviço Gráfico do Ministério da Educação, 1940.

Baro, Roulox. "Relation du voyage de Roulox Baro. Interprete et Ambassadeur ordinaire de la Compagnie des Indes d'Occident de la part des illustrissimes seigneurs des Provinces Unies au pays des Tapuies dans las terres fermes du Brasil. Commencé le troisiesme Avril 1647. Et fini le quatorsiesme Juillet de la mesme anné.” In Relations veritables et curieuses de lisle de Madagascar et du Bresil ave l'histoire de la derniere guerre faite au Bresil, entre les Portugais et les Hollandois, ed. Pierre Moreau, 197-246. Paris: Chez Augustin Courbé, 1651.

Barroso, Gustavo. Terra de sol. Fortaleza: Editora ABC, 2006.

Bertelli, Antonio de Pádua. Os fatos e os acontecidos com a poderosa e soberana Nação dos Índios Cavaleiros Guaycurús no Pantanal do Mato Grosso, entre os anos de 1526 até o ano de 1986. São Paulo: Uyara, 1987.

Boeseman, Marinus, L. B. Holthuis, M. S. Hoogmoed, and C. Smeenk. "Seventeenth century drawings of Brazilian animals in Leningrad." Zoologische Verbandelingen Leiden 267:12 (1990): 1-189.

Bolinder, Gustav. Indians on horseback. London: Dennis Dobson, 1957. 
Brienen, Rebecca Parker. "From Brazil to Europe: The zoological drawings of Albert Eckhout and George Marcgraf." In Early modern zoology. The construction of animals in science, literature and the visual arts, ed. Karl Enenkel and Paul Smith, 273-314. Leiden: Brill, 2007.

Brown, Cecil. Lexical acculturation in Native American languages. Oxford: Oxford University Press, 1999.

Brouwer, Henry. "Relación del viaje de Hendrick Brouwer a Valdivia en 1643". In Opusculos varios de J.T. Medina, ed. Guillermo Felliú Cruz, 81-127. Santiago: Imprenta Universitaria, 1928[1646].

Camphora, Ana Lúcia. Animais e sociedade no Brasil dos séculos XVI a XIX. Rio de Janeiro: ABRAMVET, 2017.

Capistrano de Abreu, João. Capitulos de história colonial: 1500-1800. Brasília: Conselho Editorial do Senado Federal, 1998.

Carvalho, Padre Miguel de. "Descrição do sertão do Piauí remetida ao Ilmo. e Rmo. Sr. Frei Francisco de Lima, Bispo de Pernambuco.” In As guerras dos Palmares: subsidios para sua história, ed. Ernesto Ennes, 370-389. São Paulo: Companhia Editora Nacional, 1938.

Cascudo, Luís da Câmara. V aqueiros e cantadores. São Paulo: Global, 2004. Cavignac, Julie. "A índia roubada: estudo comparativo da história e das representações das populações indígenas do Rio Grande do Norte." Caderno de História 2:2 (1995): 83-92.

Cooper, John. "The Patagonian and Pampean hunters." In Handbook of South American Indians - volume 1: The marginal tribes, ed. Julian Steward, 127-168. Washington: Government Printing Office, 1946.

_- "The Chono." In Handbook of South American Indians - volume 1: The marginal tribes, ed. Julian Steward, 47-54. Washington: Government Printing Office, 1946.

Costa, Luiz. The owners of kinship: asymmetrical relations in Indigenous Amaronia. Chicago: HAU Books, 2017.

Cruz, Carlos Henrique Alves. "Tapuias e mestiços nas aldeias e sertões do Norte: conflitos, contatos e práticas 'religiosas' nas fronteiras coloniais." PhD diss., Universidade Federal Fluminense, 2018.

Cunha, Euclides da. Os sertões. Rio de Janeiro: Ediouro, 1967.

De Bruin, Alexander. Frans Post: Animals in Brazil. Amsterdam: Rjksmuseum, 2016.

Descola, Philippe. "Pourquoi les indiens d'Amazonie n'ont-il pas domestiqué le pecari?" In De la prébistoire aux missiles balistiques. 
L'intelligence sociale des techniques, ed. Bruno Latour and Pierre Lemmonier, 329-344. Paris: La Découverte, 1994.

Dyck, Ian. "Does rodeo have roots in ancient Indian traditions?" Plains Anthropology 4:157 (1996): 205-219.

Egmond, Florike and Peter Mason. "Albert E(e)ckhout, court painter." In Albert Eckhout: a Dutch artist in Brazil, ed. Quentin Buvelot, 108127. Den Haag: Royal Cabinet of Paintings Mauritshuis/Waanders Publishers, 2004.

Ehrenreich, Paul."Über einige ältere Bildnisse südamerikanischer Indianer." Globus: Illustrierte Zeitschrift für Länder- und Völkerkunde 66: 6 (1894): 81-90 (plus 3 pages with plates).

- "Sobre alguns retratos de índios sul-americanos." Revista do Instituto Archeologico e Geographico Pernambucano 12:65 (1905): 18-46.

Ellis, Olivia. Organizing indigeneity among the Xukuru do Ororubá of Brazil. Master's thesis, University of 'Texas, 2010.

Erikson, Philippe. "The social significance of pet keeping among Amazonian Indians." In Companion animals and us, ed. Anthony Podbersceck, Elizabeth S. Paul and James Serpell, 7-26. Cambridge: Cambridge University Press, 2000.

Ewers, John. The horse in Blackfoot Indian culture. Washington: Smithsonian Institution Press, 1985.

Ferret, Carole. Une civilisation du cheval: les usages de l'équide de la steppe à la tä̈ga. Paris: Éditions Belin/IFEAC, 2009.

Galindo, Marcos. O governo das almas: a expansão colonial no país dos Tapuias (1651-1798). São Paulo: Hucitec, 2017.

Galvão, Eduardo. "O cavalo na América indígena: nota prévia a um estudo de mudança cultural.” Revista do Museu Paulista (nova Série) 14 (1963): 221-232.

George, Wilma. Animals and maps. London: Secker and Warburg, 1969.

Graham, Robert Cunninghame. The horses of the conquest: a study of the steeds of the Spanish Conquistadors. Norman: University of Oklahoma Press, 1949.

Gregson, Ronald. "The influence of horse on Indian cultures of Lowland South America." Ethnohistory 16:1 (1969): 33-50.

Goulart, José Alípio. O cavalo na formação do Brasil. Rio de Janeiro: Editora Letras e Artes, 1964.

Hajstrup, Peter Hansen. Viagem ao Brasil (1644-1654). Recife: Cepe Editora, 2016. 
Harris, Susanna and André Veldmeijer, eds. Why leather? The material and cultural dimensions of leather. Leiden: Sidestone Press, 2014.

Hemming, John. Red gold: The conquest of the Brazilian Indians. Cambridge: Harvard University Press, 1978.

Henfrey, Thomas. Wapishana ethnoecology: a case study from the South Rupununi, Guyana. Lethem: The Wapishana Wadauniinao Ati'o, 2017.

Herberts, Ana Lucia. "Os Mbayá-Guaicurú: área, assentamento, subsistência e cultura material." Master's thesis, Universidade do Vale do Rio dos Sinos, 1998.

Hoogvliet, Margriet. "De ignotis quarumdam bestiarum naturis: texts and images from the bestiary on Mediaeval maps of the world." In Animals and the symbolic in Mediaeval art and literature, ed. L. R. Houwen, 189-208. Groningen: Egbert Forsten, 1997.

IBGE (Instituto Brasileiro de Geografia e Estatística). Geografia do Brasil: grandes regiões Meio-Norte e Nordeste. Rio de Janeiro: IBGE (Biblioteca Geográfica Brasileira, série A, v. 3, n. 17), 1962.

Iverson, Peter. When Indians became cowboys: Native peoples and cattle ranching in the American West. Norman: University of Oklahoma Press, 1994.

Johnson, John. "The introduction of the horse into the Western Hemisphere." The Hispanic American Historical Review 23:4 (1943): 587-610.

Joppien, Rüdiger. "The Dutch vision of Brazil: Johan Maurits and his artists." In Johan Maurits van Nassau-Siegen: a humanist prince in Europe and Brazil. Essays on the occasion of the tercentenary of his death, ed. Ernst van den Boogaart, H. R. Hoetnik, and J.P.J. Whitehead, 297-376. The Hague: Johan Maurits van Nassau Stichting, 1979.

Kosby, Marília, Daniel Vaz Lima and Flávia Rieth. "Centauros de motocicleta: o cavalo como testemunha do 'processo domesticatório' do gaúcho.” Horizontes Antropológicos 23:48 (2017): 197-223.

Levine, Marsha. "Domestication and early history of the horse." In The domestic horse: the origins, development and management of its behavior, ed. D. S. Mills and S. M. McDonnell, 5-22. Cambridge: Cambridge University Press, 2005.

Libri Principis, volume I. Rio de Janeiro: Editora Index, 1993.

Clarissa M. Lima, "Deus no céu e os índios na Terra: morte e vida numa aldeia Xukuru do Ororubá.” PhD diss., Universidade Federal de São Carlos, 2019. 
Lopes, Fátima Martins. Índios, colonos e missionários na colonização da capitania do Rio Grande do Norte. Natal: IHGRN, 1998.

Lowie, Robert. "The 'Tapuya'." In Handbook of South American Indians, vol. 1: The Marginal Tribes, ed. Julian H. Steward, 553-556. Washington: Government Printing Office, 1946.

Macedo, Helder Medeiros de. "Relações entre índios e colonos nos sertões do Seridó, Capitania do Rio Grande, no século XVIII." Clio. Série Arqueológica 28 (2013): 1-17.

Mariante, Arthur, and Neusa Cavalcante. Animais do descobrimento: raças domésticas da história do Brasil. Brasilia: Embrapa, 2006.

Maybury-Lewis, David. "Some crucial distinctions in Central Brazilian ethnology." Anthropos, bd. 60, h. 1/6 (1965): 340-358.

Mead, David. "Caiapó do Sul, an ethnohistory (1610-1920)." PhD diss., University of Florida, 2010.

Melatti, Júlio César. Índios e criadores: a situação dos Krahó na área pastoral do Tocantins. Rio de Janeiro: I.C.S/UFRJ, 1967.

Meuwese, Mark. Brother in arms, partners in trade: Dutch-indigenous alliances in the Atlantic world, 1595-1674. Leiden: Brill, 2012.

Mitchell, Peter. Horse nations: the worldwide impact of the horse on Indigenous societies post-1492. Oxford: Oxford University Press, 2015.

Monteiro, John Manuel. "The crises and transformations of invaded societies: coastal Brazil in the sixteenth century." In The Cambridge History of the Native Peoples of the Americas, ed. Frank Salomon and Stuart B. Schwartz, 973-1023. Cambridge: Cambridge University Press, 1999.

—. "Review of Oliveira, João Pacheco de. 1999. Ensaios de antropologia histórica. Rio de Janeiro: Editora UFRJ." Mana 8:1 (2002): 234-238.

Mott, Luiz. "Os índios e a pecuária nas fazendas de gado do Piauí colonial." Revista de Antropologia XXII (1979): 61-78.

Nacuzzi, Lidia. Identidades impuestas: Tebuelches, Aucas y Pampas en el Norte de la Patagonia. Buenos Aires: Sociedad Argentina de Antropología, 1998.

_- "Los grupos nómades de la Patagonia y el Chaco en el siglo XVIII: identidades, espacios, movimientos y recursos económicos ante la situación de contacto. Una reflexión comparativa." Chungara: Revista de Antropología Chilena 30:2 (2007): 221-234.

Nantes, Padre Martinho de. Relação de uma missão no rio São Francisco. São Paulo: Editora Nacional; Brasília: INL, 1979 [1706]. 
Nimuendajú, Curt. The eastern Timbira. Berkeley: University of California Press (University of California Publications in American Archaeology and Ethnology, no. 41), 1946.

Nogueira de Queiroz, Albérico, Olivia de Carvalho, Suely Martinelli, Márcia Guimarães, and Cristiana Santana. "Distinctive archaeofauna occurrences recovered in Brazil: Iberian contribution in archaeological sites during the colonial period." In Book of Abstracts of the Encontro de Zooarqueologia Ibérica 2017 (EZI2017) and 5 Reunião Científica de Arqueomalacologia da Península Ibérica (5RCAPI). 26-29 April 2017, Faro - Portugal, ed. Maria João Valente, Cláudia Costa and Cleia Detry, 14. Faro: Universidade do Algarve, 2017.

Nordenskiöld, Erland. Deductions suggested by the geographical distribution of some post-columbian words used by the Indians of South America. Göteborg: Elanders Boktryckeri Aktiebolag, 1922.

Palermo, Miguel A. "Reflexiones sobre el llamado 'complejo ecuestre' en la Argentina." Runa 16 (1986): 157-178.

-. "La innovación agropecuaria entre los indígenas PampeanoPatagonicos: genesis y procesos." Anuario del IEHS 3 (1988): 43-90.

Panich, Lee. "Indigenous vaqueros in colonial California: labor, identity, and autonomy." In Foreign objects: rethinking Indigenous consumption in American archaeology, ed. Craig Cipolla, 187-203. Tucson: The University of Arizona Press, 2017.

Picon, François-René. Pasteurs du Nowveau Monde. Adoption de l'élevage chez les indiens Guajiros. Paris: Éditions de la Maison des Sciences de l'Homme, 1983.

—_. "Le cheval dans le Noveau Monde: histoires culturelles." Études Rurales 151-152 (1999): 51-75.

Pinto, Estevão. Etnologia Brasileira (Fulniô - Os últimos Tapuias). São Paulo: Companhia Editora Nacional, 1956.

Pompa, Cristina. "Religião como tradução: missionários, Tupi e "Tapuia" no Brasil colonial." PhD diss., Universidade Estadual de Campinas, 2001.

Puntoni, Pedro. A guerra dos bárbaros: povos indigenas e colonização do sertão Nordeste do Brasil, 1650-1720. São Paulo: Hucitec/Edusp, 2002.

Restall, Matthew. Sete mitos da conquista espanbola. Rio de Janeiro: Civilização Brasileira, 2006.

Ribeiro, Darcy. Os indios e a civilização. São Paulo: Companhia das Letras, 1996. 
Ribeiro, Eduardo Rivail. "Macro-Jê." In Encyclopedia of Language and Linguistics, vol. 7, ed. Keith Brown, 422-426. Oxford: Elsevier, 2006.

—. "Tapuya connections: language contact in Eastern Brazil." Liames 9 (2009): 61-79.

Roller, Heather. "On the verge of total extinction? From Guaykurú to Kadiwéu in nineteenth-century Brazil." Ethnohistory 65:4 (2018): 647-670.

Saeger, James. The Chaco mission frontier: the Guaycuruan experience. Tucson: The University of Arizona Press, 2000.

Saignes, Thierry. "La guerra 'salvaje' en los confines de los Andes y del Chaco: la resistencia chiriguana a la colonización europea." Quinto Centenario 8 (1985): 103-123.

Santos Junior, Valdeci dos. Os indios Tapuias do Rio Grande do Norte Antepassados esquecidos. Mossoró: Universidade do Estado do Rio Grande do Norte/Grupo de Pesquisa História da Região Oeste do Rio Grande do Norte (Coleção Mossoroense, volume 1532as), 2008. Santos, Juvandi de S. As fazendas de gado dos jesuitas na Paraíba colonial. João Pessoa: Uepb/CNPq (Série Arqueologia/Paleontologia, v. 5). 2015. Santos, Solon Araújo. Os Payayá no sertão das Jacobinas (1651-1706). Curitiba: Editora Prismas, 2017.

Saumade, Frédéric. "Ganadería, tauromaquia y subversión ritual: el retorno del mexicano y del indígena en el rodeo americano." In Comprender los rituales ganaderos en los Andes y más allá, ed. Juan Javier Rivera Andía, 365-400. Bonn/Aachen: Shaker Verlag, 2014.

Schindler, Helmut. "Equestrian and Non-Equestrian Indians of the Gran Chaco during the Colonial Period." Indiana 10 (1985): 451-464.

Schuller, Rudolf. "Zur Affinität der Tapúya-Indianer des "Theatrum Rerum Naturalium Brasiliae'." Internationales Archiv für Ethnographie 21 (1912): 78-98.

Souza, Gabriel Soares de. Tratado descritivo do Brasil em 1587. São Paulo: Companhia Editora Nacional, 1938 [1587].

Taylor, Michelle. Feral and semi feral horses: a useful guide and overview. Scotts Valley: CreateSpace Independent Publishing Platform, 2016.

Teensma, Benjamin. "O diretorado do Predicante Jodocus van Stetten no ano 1645, sobre uma suposta mina de prata nas margens do Rio Sucuru na Paraíba." In Brazilie in de Nederlandse archieven (1624-1654): Oude West Indische Compagnie: correspondentie van de Heren XIX en Notulen van de Hoge en Secrete Raad van Brazilië / O Brasil em arquivos 
neerlandeses (1624-1654): Companhia das Índias Ocidentais velha: Cartas enviadas pelos Diretores XIX Atas diárias do Alto e Secreto Conselho do Brasil, ed. Marianne Wiesebron, 25-47. Leiden: Leiden University Press, 2011.

Teixeira, Dante Martins. "A imagem do paraíso: uma iconografia do Brasil Holandês (1624-1654) sobre a fauna e a flora do Novo Mundo.” In Miscelânia Cleyeri. Rio de Janeiro: Index (Coleção Brasil Holandês), 1995.

Theatrum Rerum Naturalium Brasiliae - Tomus III - Icones Animalium. BrasilHolandês/Dutch Brazil: Icones Animalium/Icones Vegetabiliuum. Rio de Janeiro: Editora Index, 1993.

van den Boogaart, Ernst. "Infernal allies: The Dutch West India Company and the Tarairiu, 1631-1654." In Johan Maurits van NassauSiegen: a bumanist prince in Europe and Brazil. Essays on the occasion of the tercentenary of his death, ed. Ernst van den Boogaart, H. R. Hoetnik, and J. P. J. Whitehead, 519-538. The Hague: The Johan Maurits van Nassau Stichting, 1979.

van Gelder, Hendrik E. "Twee Braziliaanse schildpadden door Albert Eckhout." Oud Holland - Journal for Art of the Low Countries 75:1 (1960): 5-29.

Vander Velden, Felipe. Inquietas companhias: sobre os animais de criação entre os Karitiana. São Paulo: Alameda, 2012.

Vangelista, Chiara. Confini e frontiere: alleanze e conflitti inter-etnici in America Meridionale, sec. XVIII. Torino: Il Segnalibro, 2001.

Whitehead, Peter James. "Georg Markgraf and Brazilian zoology." In Johan Maurits van Nassau-Siegen: a humanist prince in Europe and Brazil. Essays on the occasion of the tercentenary of his death, ed. Ernst van den Boogaart, H. R. Hoetnik, and J. P. J. Whitehead, 424-471. The Hague: Johan Maurits van Nassau Stichting, 1979.

Whitehead, Peter James and Marinus Boeseman. A portrait of Dutch 17th century Brazil: animals, plants and people by the artists of Johan Maurits of Nassau. Amsterdam: North-Holland Publishing Company (Koninklijke Nederlandse Akademie van Wetenschappen Verhandelingen Afd. Natuurkunde, Tweede Reeks, deel 87), 1989. 